\title{
Gender differences and determinants of health related quality of life in coronary patients: a follow-up study
}

\author{
María Dueñas ${ }^{1}$, Carmen Ramirez $^{1}$, Roque Arana $^{2}$ and Inmaculada Failde ${ }^{1 *}$
}

\begin{abstract}
Background: The role of gender differences in Health Related Quality Life (HRQL) in coronary patients is controversial, so understanding the specific determinants of HRQL in men and women might be of clinical importance. The aim of this study was to know the gender differences in the evolution of HRQL at 3 and 6 months after a coronary event, and to identify the key clinical, demographic and psychological characteristics of each gender associated with these changes.

Methods: A follow-up study was carried out, and 175 patients (112 men and 63 women) with acute myocardial infarction (AMI) or unstable angina were studied. The SF-36v1 health questionnaire was used to assess HRQL, and the GHQ-28 (General Health Questionnaire) to measure mental health during follow-up. To study the variables related to changes in HRQL, generalized estimating equation (GEE) models were performed.

Results: Follow-up data were available for 55 men and 25 women at 3 months, and for 35 men and 12 women at 6 months. Observations included: a) Revascularization was performed later in women. b) The frequency of rehospitalization between months 3 and 6 of follow-up was higher in women c) Women had lower baseline scores in the SF-36. d) Men had progressed favourably in most of the physical dimensions of the SF-36 at 6 months, while at the same time women's scores had only improved for Physical Component Summary, Role Physical and Social Functioning; e) the variables determining the decrease in HRQL in men were: worse mental health and angina frequency; and in women: worse mental health, history of the disease, revascularization, and angina frequency.

Conclusions: There are differences in the evolution of HRQL, between men and women after a coronary attack. Mental health is the determinant most frequently associated with HRQL in both genders. However, other clinical determinants of $\mathrm{HRQL}$ differed with gender, emphasizing the importance of individualizing the intervention and the content of rehabilitation programs. Likewise, the recognition and treatment of mental disorders in these patients could be crucial.
\end{abstract}

Keywords: Gender, HRQL, SF-36, Coronary patients

\section{Background}

Coronary heart disease (CHD) is the leading cause of death and disability among both women and men $[1,2]$. However, coronary disease affects men and women differently. Men suffer four times as many coronary events as women, [3] but the first episode of an acute myocardial infarction is more likely to be fatal in women. In recent

\footnotetext{
* Correspondence: inmaculada.failde@uca.es

${ }^{1}$ Área de Medicina Preventiva y Salud Pública. Universidad de Cádiz. Spain Full list of author information is available at the end of the article
}

years, epidemiological studies have demonstrated that women with coronary disease often remain undiagnosed, or if diagnosed, the severity of the illness is frequently underestimated [4]. Furthermore, compared to men, women return to work and use cardiac rehabilitation programmes less frequently [5].

It has been reported that women with coronary disease are older, have a higher burden of comorbid illnesses,[6] are more often widowed or living alone, have more depressive symptoms, and have poorer psychosocial

\section{Biomed Central}


adjustment following a coronary event [7-10]. However, the reasons why the disease affects men and women differently remain unclear.

Health-related quality of life (HRQL) is a commonly used measure of results for defining health in terms of both how individuals feel (distress and well-being) and how they evaluate their health and prospects for the future. Different studies performed in the general population have shown that HRQL is worse in women than in men [1,11-19]. Likewise, several authors have shown that women with coronary disease report significantly poorer physical functioning and mental health than men $[5,11,16,20,21]$.

Different factors have been associated with HRQL in patients with coronary heart disease. Brink et al [1] reported that depression measured at 1 week after an acute myocardial infarction predicted women's physical health (PCS) at 1 year. Other authors have shown that smoking, regular alcohol consumption, and overweight are the most common risk factors for worse HRQL in men, while psychological distress, role pressure, and less strenuous exercise are more characteristic of women [22].

Prior data suggest that women with cardiac disease are more likely than men to be confronted with continuing demands in the home environment, and may be more likely to neglect health care needs [17]. Thus, Emery et al [17] hypothesized that quality of life would be more strongly associated with social support among women than among men.

Despite all the considerations above, it is necessary to improve the knowledge of the gender differences in HRQL and the effect that sociodemographic, clinical and psychological variables have on the evolution of HRQL after a coronary attack in men and women. Therefore, we carried out this study to know the gender differences in the evolution of HRQL at 3 and 6 months after a coronary event, and to identify the key clinical, demographic and psychological characteristics associated with these changes for each gender. Thus, it was hypothesized that the factors determining the evolution of HRQL in men and women would be different. It was further hypothesized that HRQL would be strongly associated with mental health, especially in women.

\section{Methods}

A follow-up study was carried out in the cardiology unit of a university hospital in the south of Spain (800 beds), where 186 consecutive patients admitted for a suspected acute episode of coronary heart disease were identified. 175 of the patients were diagnosed with acute myocardial infarction (AMI) or unstable angina on the basis of clinical, biochemical and electrocardiographic criteria, and on the basis of their hospital discharge report.
Patients with non-ischemic or non-cardiological precordial pain were excluded.

Patients were considered to have had an AMI if they met at least 2 of the following criteria: precordial pain lasting 20 minutes or more; CK (creatine kinase) and CK-M (creatine kinase-muscle) above normal values in at least 2 serum samples; and/or the appearance of the Q wave in at least 2 ECG (electrocardiography) readings.

Patients were classified as having unstable angina if they suffered precordial pain similar to the first group, and showed changes in the ST segment of the ECG, without a high enzyme level.

A previously-trained interviewer, who was not the cardiologist who made the clinical evaluation, obtained the information at baseline (9 days; SD: 7.5) after admission when the patient was clinically stable, and 3 months and 6 months after discharge. Before inclusion, all the patients were asked for their informed consent and agreed to participate $(\mathrm{n}=175)$.

The study was conducted in agreement with the Helsinki Declaration and with standard working procedures and protocols, and it was approved by the Clinical Research Ethics Committee at the hospital, ensuring adherence to the norms of good clinical practice.

Sociodemographic and clinical information was obtained at baseline from a structured questionnaire and from the patients' clinical records. These variables were cardiovascular risk factors (consumption of tobacco, hypertension, hypercholesterolemia, obesity, physical activity and diabetes) and clinical information (previous history of coronary heart disease, ejection fraction, diagnostic group). The existence of comorbidity was assessed if another chronic pathology (digestive, respiratory, osteomuscular, neurological or of another nature) was explicitly documented in the patients' clinical records.

HRQL was assessed at baseline, 3 and 6 months using the eight specific and the two Physical and Mental Component Summaries (PCS and MCS) of the SF-36v1 health questionnaire. Each of the eight dimensions of the questionnaire (PF: physical functioning; RP: role physical; BP: body pain; GH: general health; VT: vitality; SF: social functioning; RE: role emotional; $\mathrm{MH}$ : mental health) were coded, aggregated and transformed into a scale from 0 (the worst state of health for that dimension) to 100 (the best state of health). The summary indices (PCS and MCS) were calculated using a z-score transformation for each dimension using the means and standard deviations in the SF-36 of the Spanish population. Then, the aggregate scores for the physical and mental component scale scores were computed. In the case of the PCS this involved multiplying each SF-36 scale $\mathrm{z}$-score by its respective factor score coefficients. 
The MCS scores were calculated in the same way. Finally, these scores were standarized to a T-score where the mean was set to 50 and the SD to 10 [23].

Mental health was also measured 3 times (baseline, 3 and 6 months) during follow-up using the GHQ-28 (General Health Questionnaire), an instrument developed as a screening method to detect non-psychotic psychiatric disorders. The 28 -item version was translated into Spanish and validated by Lobo et al [24] and has already been validated as a means of detecting problems in cardiology patients [25]. The questionnaire consists of 28 items and the score in the scale ranges between 0 and 28 points, a higher score indicating a higher probability of mental disorders. The cut-off point recommended for the questionnaire is $\geq 6$ points, thus providing a sensitivity of $76.9 \%$ and a specificity of $90.2 \%$ [24].

The variables rehospitalization, return to work and frequency of angina were all assessed twice during follow-up (3 and 6 months). However, to consider these variables in a longitudinal form a variable was created taking the value 0 in all patients as baseline data. With the information from this variable and the 2 assessments carried out (3 and 6 months), a new variable was constructed and it was coded as 0: no event occurred to the patients during the whole period, 1: the event occurred to patients during the first 3 months, and 2: the event occurred to the patients between 3 and 6 months.

The revascularization treatment was evaluated three times during follow-up. As with the variables mentioned above (rehospitalization, return to work and frequency of angina), a new variable was constructed with the information from the 3 assessments (baseline, 3 and 6 months) of the revascularization treatment and this new variable was coded as 0 : patients not undergoing revascularization during the whole period, 1 : patients undergoing revascularization during admission, 2: patients undergoing revascularization during the first 3 months after discharge, and 3: patients undergoing revascularization between 3 and 6 months after discharge.

\section{Statistical Analysis}

A descriptive analysis was conducted, and the chi-square test and Student $\mathrm{t}$-test were performed to compare the characteristics of the men and women responding and not responding at 3 and 6 months of follow-up.

Likewise, as a previous exploratory analysis, a repeated measures ANOVA and Friedman's test were used to assess the changes in SF-36 scores in each gender during follow-up, using the Bonferroni test and Wilcoxon test for post hoc comparisons. A result was considered statistically significant if the $\mathrm{p}$ value was $<0.05$.

To assess the evolution of each dimension of the SF36 questionnaire during the study, and to find out which sociodemographic and clinical variables affected this evolution, a regression model using Generalized Estimating Equations (GEE) was constructed for each gender and for each dimension. These models are an extension of generalized linear models, constructed to produce more efficient estimates than ordinary least squares regression in repeated measures studies because they account for correlations between observations. GEE models are more flexible than other models as they allow subjects with incomplete data to be included in the analyses. If a particular subject is missing one or more out of $\mathrm{T}$ repeated measurements, the remaining available data from the other measurements for that particular subject are used in the analyses [26]. Also, the dependent variable in the model can have a distribution different to the normal distribution and the predictor variables included in the models can be continuous variables, ordinals or categorical variables [27]. These models have not been extensively used in healthcare research.

The dataset is presented in longitudinal form, where for each patient there were as many registers as evaluations. The dependent variable included in each model was the corresponding dimension's score at the 3 times studied for each gender, and the independent variables were: the follow-up time (baseline, 3 and 6 months), sex, age, educational level, diagnostic group (AMI versus unstable angina), previous history of coronary heart disease, ejection fraction, comorbidity and risk factors. The variables rehospitalization, return to work, revascularization and angina frequency were introduced into the models in their new, recoded form, as stated above, and the GHQ-28 score was entered as a time-varying covariate. The criteria used for selecting the co-variables included in the models were statistical (significance observed in the bivariate analysis, $P<.05$ ) and the clinical criteria recognized in the literature. To select the best model, the parameters of goodness of fit were used. The parameters were expressed by "quasi-likelihood under the independence model criterion" (QIC) and "corrected quasi-likelihood under the independence model criterion" (QICC), with the lowest possible values [28]. The analysis was performed using the SPSS.v17 program.

\section{Results}

Of the 175 patients who were initially included in the study, 112 (64\%) were men and 63 (36\%) were women. Around $90 \%$ of both the men and women had one or more cardiovascular risk factors, arterial hypertension (52.7\% of men and $68.3 \%$ of women) being the most common. Likewise, the presence of comorbidity or a previous history of coronary disease was observed in over $50 \%$ of the patients, with a similar distribution in 
both genders. One of the most significant differences by gender was detected in the GHQ-28 score, where 32.2\% of the men scored $\geq 6$ compared to $42.9 \%$ of the women $(P<.001)$ (Table 1$)$.

Table 1 Characteristics of the patients for each gender at baseline

\begin{tabular}{|c|c|c|c|}
\hline SOCIODEMOGRAPHIC VARIABLES & MEN & WOMEN & $P$ \\
\hline \multirow[t]{2}{*}{ Age (Mean SD) } & $N=112$ & $N=63$ & 0.11 \\
\hline & $67.11(10.9)$ & $69.76(9.9)$ & \\
\hline Age group & $N=110$ & $N=62$ & 0.55 \\
\hline$<=60$ & $29(25.9)$ & 12(19) & \\
\hline $61-70$ & 38(33.9) & $22(34.9)$ & \\
\hline \multirow[t]{2}{*}{$>70$} & $43(38.4)$ & $28(44.4)$ & \\
\hline & $\mathrm{N}=112 \mathrm{n}(\%)$ & $N=63 n(\%)$ & \\
\hline Educational Levels & & & 0.01 \\
\hline $\begin{array}{l}\text { Illiterate - No Educational Level } \\
\text { completed }\end{array}$ & $45(40.2)$ & $37(58.7)$ & \\
\hline Primary & $41(36.6)$ & $22(34.9)$ & \\
\hline Secondary and University & $26(23.2)$ & $4(6.3)$ & \\
\hline \multicolumn{4}{|l|}{ CLINICAL VARIABLES } \\
\hline Diagnostic group & & & 0.84 \\
\hline Acute myocardial infarction & $48(42.9)$ & 26(41.3) & \\
\hline Unstable angina & $64(57.1)$ & $37(58.7)$ & \\
\hline GHQ-28 (baseline) & & & 0.01 \\
\hline$<6$ & $86(76.8)$ & $36(57.1)$ & \\
\hline$\geq 6$ & $26(23.2)$ & $27(42.9)$ & \\
\hline GHQ-28 (Mean SD) & $3.04(4.1)$ & $6.95(6.02)$ & 0.00 \\
\hline Tobacco & & & 0.00 \\
\hline Smoker & $41(36.6)$ & $2(3.2)$ & \\
\hline Non-smoker & $71(63.4)$ & $61(96.8)$ & \\
\hline \multicolumn{4}{|l|}{ Diabetes } \\
\hline Yes & 39(34.8) & $30(47.6)$ & 0.10 \\
\hline \multicolumn{4}{|l|}{ Hypercholesterolemia } \\
\hline Yes & $47(42)$ & $26(41.3)$ & 0.93 \\
\hline \multicolumn{4}{|l|}{ High blood pressure } \\
\hline Yes & $59(52.7)$ & $43(68.3)$ & 0.05 \\
\hline \multicolumn{4}{|l|}{ Obesity (BMI $\geq 30)$} \\
\hline Yes & $26(23.2)$ & $26(41.3)$ & 0.01 \\
\hline \multicolumn{4}{|l|}{ Physical Activity } \\
\hline Yes & $60(53.6)$ & 20(31.7) & 0.01 \\
\hline \multicolumn{4}{|l|}{ Previous history of CHD. } \\
\hline Yes & $65(58)$ & $34(54.0)$ & 0.60 \\
\hline \multicolumn{4}{|l|}{ Comorbidity } \\
\hline Yes & $70(62.5)$ & $40(63.5)$ & 0.90 \\
\hline \multicolumn{4}{|l|}{ Ejection fraction } \\
\hline$<50$ & $32(28.6)$ & 12(19) & 0.16 \\
\hline$\geq 50$ & $80(71.4)$ & $51(81)$ & \\
\hline Risk factor & & & 0.80 \\
\hline None & $12(10.7)$ & $6(9.5)$ & \\
\hline One or more & $100(89.3)$ & $57(90.5)$ & \\
\hline
\end{tabular}

BMI: Body mass index CHD: Coronary Heart Disease.
Figure 1 shows that, of the patients who began the study, 55 men (49.1\%) and 25 women (39.7\%) remained at 3 months, and 35 men (31.3\%) and only 12 women (19.1\%) at 6 months. However, there were no significant differences in socio-demographic and clinical characteristics between the responding and non-responding patients at 3 and at 6 months, except that the women who remained in the study were younger (73 vs 65 years at 3 months, $P<.05$; 71 vs 65 years at 6 months, $P<.05$ ).

Figure 1 also shows that the percentage of men who had undergone revascularization at baseline was higher than that of women, but a higher percentage of women underwent this operation at a later time (3 to 6 months $(P=0.01))$. It is also worth pointing out that the women had more episodes of angina throughout the whole of follow-up, but this difference was not statistically significant; they were also rehospitalised more often between 3 and 6 months $(P=0.02)$.

Regarding the differences in the baseline scores in the dimensions of the SF-36, the men remaining in the study at 3 months had lower scores only in the PF dimension when compared with the patients who dropped out during follow-up. On the other hand, the women who remained at 6 months had lower baseline scores in the VT, SF and MCS dimensions.

The raw analysis of the differences between each of the eight specific and the two summary dimensions of the SF-36 during follow-up shows a significant improvement among the men in the scores obtained in the BP and GH dimensions. However, the rest of the dimensions showed no significant changes throughout followup. (Table 2)

The analysis of the raw data for women showed a significant improvement during follow-up in the scores obtained in the RP, and VT dimensions, while this was particularly so in the SF dimension (baseline score of 38.5 vs 80.2 at 3 months). However, no differences were observed in the remaining dimensions of the SF-36. (Table 2).

It is also necessary to point out that the baseline scores were lower for women than for men in all the dimensions of the SF-36. These differences were all statistically significant.

\section{Analysis of the evolution of HRQL with GEE models Men}

In the analysis of the evolution of HRQL in men, the MCS dimension was not considered worth studying because the scores remained constant during follow-up (Table 2) and they were very close to those of the Spanish reference population (mean 50, SD:10).

The analysis of the PF, BP, SF, and PCS dimensions revealed that, while scores remained unchanged at 3 months, at 6 months patients had made a significant recovery. On the contrary, the RE dimension score only 


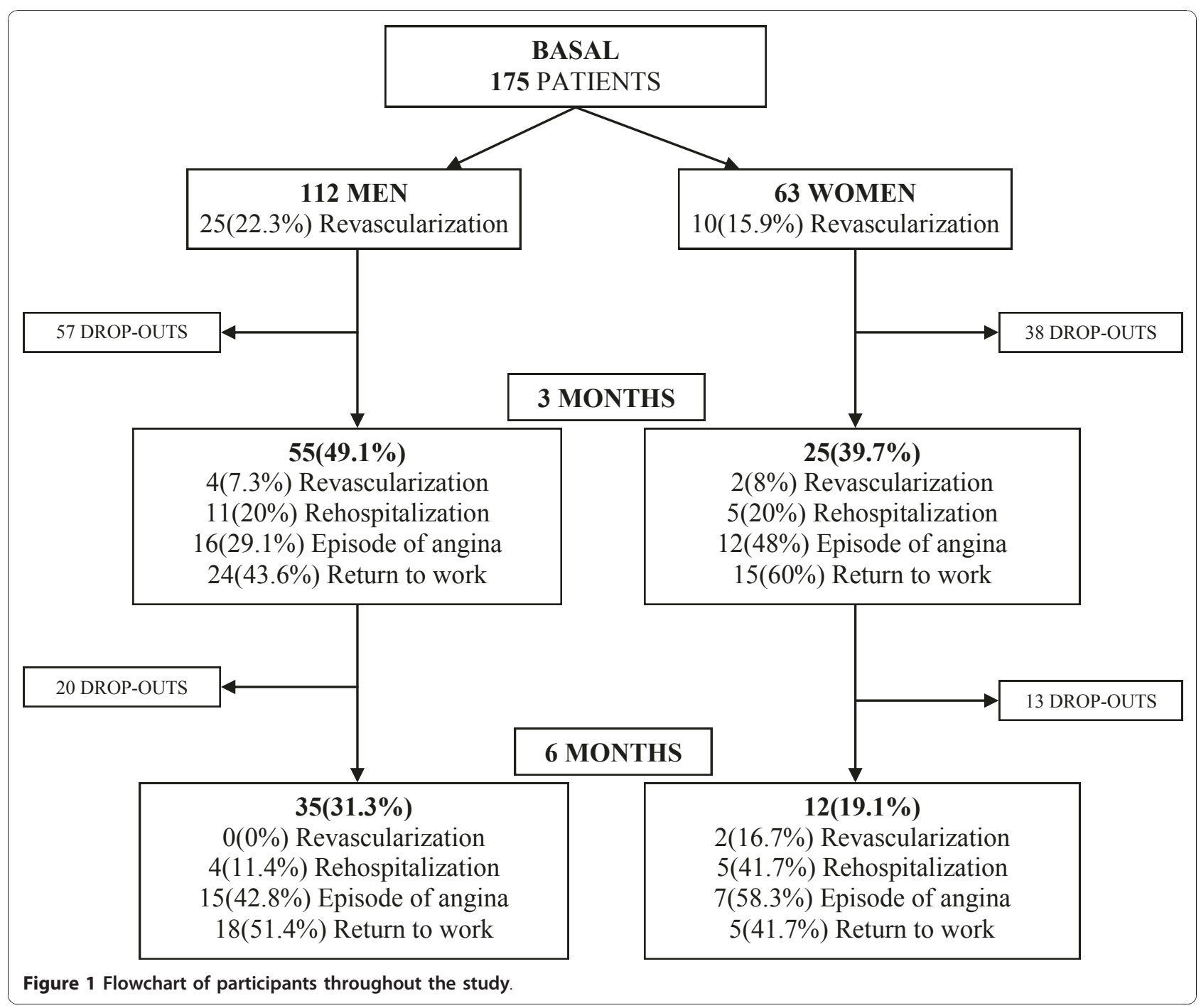

improved at 3 months; a significant increase was observed in the GH dimension at both 3 and 6 months (Table 3).

Despite not showing changes during follow-up, the $\mathrm{RP}, \mathrm{VT}$ and $\mathrm{MH}$ dimensions were also analysed to identify the factors which conditioned the lack of improvement over time.

Among the factors associated with HRQL, the patients' age was shown to have a negative effect on the evolution of the PF, RP, BP and PCS dimensions. Also, the patients who were rehospitalised or suffered an episode of angina between 3 and 6 months of the followup showed worse evolution in some dimensions of their quality of life. Furthermore, a history of coronary disease had a negative effect on the evolution of the $\mathrm{GH}$ and PCS dimensions, while the presence of comorbidity and cardiovascular risk factors negatively affected RP and $\mathrm{BP}$, respectively (Table 3 ).
As for the mental dimensions, the frequency of angina stands out as the variable having the most negative effect on SF, RE and MH (Table 3).

Lastly, it should be emphasized that the patients' mental health, measured with the GHQ-28, was the only variable associated with deterioration in all the dimensions of HRQL throughout the study. It caused a decrease of between 1.4 and 5.6 points in HRQL for every unit increase in the GHQ-28 during follow-up (Table 3).

\section{Women}

In the analysis of the evolution of HRQL in women, the scores for the RP, SF, and PCS dimensions remained unchanged at 3 months. However, they were higher at 6 months of follow-up (Tables 4 and 5).

Despite not showing changes, the other dimensions were analyzed to identify the factors which conditioned the lack of improvement over time. 
Table 2 Mean (SD) of SF-36 dimensions in Spanish population and study population during follow-up by gender

\begin{tabular}{|c|c|c|c|c|c|c|c|c|c|c|c|c|c|c|}
\hline & \multicolumn{7}{|c|}{ MEN } & \multicolumn{7}{|c|}{ WOMEN } \\
\hline & \multicolumn{2}{|c|}{$\begin{array}{c}\text { BASELINE } \\
\mathrm{N}=112\end{array}$} & \multicolumn{2}{|c|}{$\begin{array}{l}3 \text { MONTHS } \\
\mathrm{N}=55\end{array}$} & \multicolumn{2}{|c|}{$\begin{array}{c}6 \text { MONTHS } \\
\mathrm{N}=35\end{array}$} & \multirow[t]{2}{*}{$p$} & \multicolumn{2}{|c|}{$\begin{array}{c}\text { BASELINE } \\
\mathrm{N}=63\end{array}$} & \multicolumn{2}{|c|}{$\begin{array}{l}3 \text { MONTHS } \\
N=25\end{array}$} & \multicolumn{2}{|c|}{$\begin{array}{c}6 \text { MONTHS } \\
\mathrm{N}=12\end{array}$} & \multirow[t]{2}{*}{$p$} \\
\hline & Mean & SD & Mean & SD & Mean & SD & & Mean & SD & Mean & SD & Mean & SD & \\
\hline $\mathrm{PF}$ & 69.4 & 25.1 & 74.3 & 25.7 & 72.4 & 25.1 & 0.45 & 40.0 & 29.3 & 45.4 & 23.2 & 37.1 & 28.5 & 0.19 \\
\hline $\mathrm{RP}$ & 62.8 & 47.9 & 73.6 & 41.5 & 74.3 & 41.8 & 0.31 & 25.0 & 39.9 & 62.5 & 43.3 & 68.7 & 46.6 & $0.02^{* *}$ \\
\hline $\mathrm{BP}$ & 64.5 & 27.6 & 67.3 & 25.5 & 76.5 & 22.1 & $0.02^{* *}$ & 33.8 & 20.7 & 40.9 & 23.7 & 41.7 & 15.9 & 0.45 \\
\hline $\mathrm{GH}$ & 62.1 & 17.5 & 69.2 & 17.1 & 69.6 & 16.0 & $0.02^{*}$ & 45.8 & 22.4 & 55.6 & 23.1 & 53.5 & 20.9 & 0.43 \\
\hline $\mathrm{VT}$ & 69.7 & 27.1 & 73.4 & 26.5 & 74.7 & 21.8 & 0.31 & 30.8 & 21.1 & 58.7 & 28.3 & 49.6 & 31.7 & $0.003^{* *}$ \\
\hline SF & 86.9 & 26.2 & 85.0 & 29.7 & 87.5 & 29.1 & 0.89 & 38.5 & 30.8 & 80.2 & 24.7 & 71.8 & 31.6 & $0.006^{* *}$ \\
\hline $\mathrm{RE}$ & 88.6 & 26.7 & 91.4 & 28.4 & 90.5 & 28.7 & 0.79 & 41.7 & 51.5 & 47.2 & 48.1 & 66.7 & 49.2 & 0.42 \\
\hline $\mathrm{MH}$ & 70.2 & 17.1 & 73.3 & 17.5 & 72.5 & 13.8 & 0.34 & 49.7 & 13.4 & 52.0 & 25.0 & 54.0 & 21.8 & 0.93 \\
\hline PCS & 43.2 & 11.6 & 45.8 & 10.2 & 46.9 & 10.6 & 0.06 & 33.3 & 10.8 & 40.6 & 7.4 & 37.5 & 11.1 & 0.08 \\
\hline MCS & 52.3 & 7.7 & 52.5 & 9.9 & 52.2 & 7.5 & 0.97 & 35.3 & 9.4 & 41.9 & 14.3 & 44.4 & 13.1 & 0.78 \\
\hline
\end{tabular}

PF: physical functioning; RP: role physical; BP: body pain; GH: general health. PCS: physical component summary; VT: vitality; SF: social functioning; RE: role emotional; MH: mental health; MCS: mental component summary.

ANOVA test with the Bonferroni test for post hoc comparisons in men and Friedman test with the Wilkoxon test for post hoc comparison in women.

p: comparison at three times.

* statistically significant difference between baseline and 3 months

** statistically significant difference between baseline and 6 months.

No significant differences were observed between 3 months and 6 months in any dimension.

The analysis of the factors affecting the evolution of HRQL in the female population highlighted that, like men, a worse mental health, measured with the GHQ28, affected all the dimensions of the SF-36; also, a history of coronary disease led to a decrease in the scores in most dimensions of the SF-36 (Tables 4 and 5).

Being rehospitalised, suffering, an episode of angina, or undergoing revascularization were also associated with lower scores in the PF, GH, and PCS dimensions in the second period of follow-up. Furthermore, the women diagnosed with AMI showed better evolution in the PF and PCS dimensions than those with unstable angina (Table 4).

Lastly, the women who had undergone revascularization during follow-up showed worse evolution in the VT, RE, and MCS dimensions than those who had not; and among the women who had been rehospitalised, $\mathrm{MH}$ became worse over the duration of the study (Table 5).

\section{Discussion}

The role of gender differences in HRQL in coronary patients is controversial, so understanding the specific determinants of HRQL in men and women might be of clinical importance in, for example, follow-up or rehabilitation programs after a heart attack. This study was carried out to know the gender differences in the evolution of HRQL at 3 and 6 months after a coronary event, and to identify the key clinical, demographic, and psychological characteristics associated with these changes in each gender. The following results stand out: a) the greater number of men who underwent revascularization during admission and the fact that the women were operated on at a later time (between 3 and 6 months); b) the greater frequency of rehospitalization among the women between 3 and 6 months; c) the baseline scores in the SF-36 were lower among women. d) The men showed better evolution at 6 months in most of the physical dimensions, and Social Functioning. However, the women only improved in Physical Component Summary, Role Physical, and Social Functioning at 6 months. e) the variables most associated with unfavourable evolution of HRQL in the men were deterioration in mental health and angina frequency. Mental health was also a determining factor in the evolution of the women's quality of life, although this was also affected by other variables, such as a clinical history of the disease, undergoing revascularization during the second period, and angina frequency.

Most studies into HRQL in coronary patients suggest that women do not cope as well physically and psychosocially as men. However, the literature is not consistent, and it remains unclear why gender-related differences in HRQL exist among coronary patients [29]. The effect of older age or a greater frequency of comorbidity among women, or a greater tendency to carry out surgical procedures such as revascularization on men have been highlighted. In our study, comorbidity was not really a determining variable for the patients' HRQL as it only affected two dimensions of the SF-36 in the 
Table 3 Generalized Estimating Equation models for MEN of SF-36.

\begin{tabular}{|c|c|c|c|c|c|}
\hline \multicolumn{6}{|c|}{ PHYSICAL DIMENSIONS } \\
\hline & VARIABLES & B & SE & C.I. $(95 \%)$ & Sig. \\
\hline \multirow{4}{*}{$\begin{array}{l}\text { PHYSICAL FUNCTIONING } \\
\text { (PF) }\end{array}$} & Age & -0.61 & 0.18 & $(-0.97 ;-0.26)$ & .001 \\
\hline & $\begin{array}{l}\text { Frequency of angina }{ }^{1} \text { ( } \geq 1 \text { between baseline- } 3 \text { months) } \\
\text { Frequency of angina ( } \geq 1 \text { between } 3 \text { and } 6 \text { months) }\end{array}$ & $\begin{array}{l}-8.02 \\
-11.02\end{array}$ & $\begin{array}{l}6.99 \\
5.68\end{array}$ & $\begin{array}{l}(-21.73 ; 5.69) \\
(-22.16 ; 0.12)\end{array}$ & $\begin{array}{l}.251 \\
.052\end{array}$ \\
\hline & GHQ-28 & -3.47 & 0.53 & $(-4.51 ;-2.44)$ & 000 \\
\hline & $\begin{array}{l}\text { Time } 1^{5} \\
\text { Time } 2\end{array}$ & $\begin{array}{l}6.64 \\
8.82\end{array}$ & $\begin{array}{l}3.57 \\
3.72\end{array}$ & $\begin{array}{r}(-0.35 ; 13.63) \\
(1.53 ; 16.12)\end{array}$ & $\begin{array}{l}.062 \\
.018\end{array}$ \\
\hline \multirow{5}{*}{$\begin{array}{l}\text { ROLE PHYSICAL } \\
\text { (RP) }\end{array}$} & Age & -0.82 & 0.24 & $(-1.29 ;-0.36)$ & .001 \\
\hline & Comorbidity (Yes) & -14.64 & 5.11 & $(-24.66 ;-4.62)$ & .004 \\
\hline & $\begin{array}{l}\text { Rehospitalization }^{2} \text { (Between baseline-3 months) } \\
\text { Rehospitalization (Between } 3 \text { and } 6 \text { months) }\end{array}$ & $\begin{array}{r}20.60 \\
-45.09\end{array}$ & $\begin{array}{c}7.07 \\
15.37\end{array}$ & $\begin{array}{c}(6.75 ; 34.45) \\
(-75.20 ;-14.97)\end{array}$ & $\begin{array}{l}.004 \\
.003\end{array}$ \\
\hline & GHQ-28 & -5.51 & 0.76 & $(-6.99 ;-4.03)$ & .000 \\
\hline & $\begin{array}{l}\text { Time } 1^{5} \\
\text { Time } 2\end{array}$ & $\begin{array}{c}-4.83 \\
2.07\end{array}$ & $\begin{array}{l}6.04 \\
6.76\end{array}$ & $\begin{array}{c}(-11.17 ; 15.31) \\
(-16.67 ; 7.02)\end{array}$ & $\begin{array}{l}.424 \\
.759\end{array}$ \\
\hline \multirow{5}{*}{$\begin{array}{l}\text { BODY PAIN } \\
\text { (BP) }\end{array}$} & Age & -0.71 & 0.14 & $(-0.98 ;-0.44)$ & .000 \\
\hline & Risk Factor (Yes) & -13.15 & 5.07 & $(-23.09 ;-3.21)$ & .010 \\
\hline & $\begin{array}{l}\text { Frequency of angina ( } \geq 1 \text { between baseline- } 3 \text { months) } \\
\text { Frequency of angina ( } \geq 1 \text { between } 3 \text { and } 6 \text { months) }\end{array}$ & $\begin{array}{l}-3.25 \\
-14.01\end{array}$ & $\begin{array}{l}6.55 \\
5.24\end{array}$ & $\begin{array}{l}(-16.08 ; 9.58) \\
(-24.29 ;-3.74)\end{array}$ & $\begin{array}{l}620 \\
.007\end{array}$ \\
\hline & GHQ-28 & -2.77 & 0.63 & $(-4.01 ;-1.54)$ & .000 \\
\hline & $\begin{array}{l}\text { Time } 1^{5} \\
\text { Time } 2\end{array}$ & $\begin{array}{c}4.43 \\
14.16\end{array}$ & $\begin{array}{l}3.69 \\
4.56\end{array}$ & $\begin{array}{l}(-2.80 ; 11.67) \\
(5.23 ; 23.10)\end{array}$ & $\begin{array}{l}.230 \\
.002\end{array}$ \\
\hline \multirow{3}{*}{$\begin{array}{l}\text { GENERAL HEALTH } \\
\text { (GH) }\end{array}$} & Previous history of CHD (Yes) & -5.50 & 2.49 & $(-10.37 ;-0.63)$ & .027 \\
\hline & GHQ-28 & -2.13 & 0.32 & $(-2.76 ;-1.50)$ & .000 \\
\hline & $\begin{array}{l}\text { Time } 1^{5} \\
\text { Time } 2\end{array}$ & $\begin{array}{l}4.64 \\
5.16\end{array}$ & $\begin{array}{l}2.21 \\
2.36\end{array}$ & $\begin{array}{l}(0.30 ; 8.97) \\
(0.54 ; 9.78)\end{array}$ & $\begin{array}{l}.036 \\
.029\end{array}$ \\
\hline \multirow{5}{*}{$\begin{array}{l}\text { PHYSICAL COMPONENT SUMMARY } \\
\text { (PCS) }\end{array}$} & Age & -0.25 & 0.05 & $(-0.35 ;-0.14)$ & .000 \\
\hline & Previous history of CHD (Yes) & -3.29 & 1.33 & $(-5.88 ;-0.69)$ & .013 \\
\hline & $\begin{array}{l}\text { Rehospitalization }{ }^{2} \text { (Between baseline-3 months) } \\
\text { Rehospitalization (Between } 3 \text { and } 6 \text { months) }\end{array}$ & $\begin{array}{r}3.68 \\
-9.79\end{array}$ & $\begin{array}{l}1.94 \\
3.93\end{array}$ & $\begin{array}{c}(-0.12 ; 7.48) \\
(-17.48 ;-2.10)\end{array}$ & $\begin{array}{l}.058 \\
.013\end{array}$ \\
\hline & GHQ-28 & -1.46 & 0.22 & $(-1.90 ;-1.02)$ & .000 \\
\hline & $\begin{array}{l}\text { Time } 1^{5} \\
\text { Time } 2\end{array}$ & $\begin{array}{l}0.67 \\
3.44\end{array}$ & $\begin{array}{l}1.32 \\
1.43\end{array}$ & $\begin{array}{r}(-1.92 ; 3.27) \\
(0.64 ; 6.24)\end{array}$ & $\begin{array}{l}.610 \\
.016\end{array}$ \\
\hline \multicolumn{6}{|c|}{ MENTAL DIMENSIONS } \\
\hline & VARIABLES & B & SE & C.I. (95\%) & Sig. \\
\hline \multirow{3}{*}{$\begin{array}{l}\text { VITALITY } \\
\text { (VT) }\end{array}$} & Comorbidity (Yes) & -9.53 & 2.82 & $(-15.06 ;-3.99)$ & .001 \\
\hline & GHQ-28 & -3.75 & 0.52 & $(-4.77 ;-2.74)$ & .000 \\
\hline & $\begin{array}{l}\text { Time } 1^{5} \\
\text { Time } 2\end{array}$ & $\begin{array}{l}-0.88 \\
-0.87\end{array}$ & $\begin{array}{l}3.17 \\
3.38\end{array}$ & $\begin{array}{l}(-7.09 ; 5.33) \\
(-7.49 ; 5.76) \\
\end{array}$ & $\begin{array}{l}.781 \\
.797 \\
\end{array}$ \\
\hline \multirow{4}{*}{$\begin{array}{l}\text { SOCIAL FUNCTIONING } \\
\text { (SF) }\end{array}$} & Age & -0.54 & 0.18 & $(-0.89 ;-0.19)$ & .002 \\
\hline & $\begin{array}{l}\text { Frequency of angina } a^{1}(\geq 1 \text { between baseline- } 3 \text { months) } \\
\text { Frequency of angina ( } \geq 1 \text { between } 3 \text { and } 6 \text { months) }\end{array}$ & $\begin{array}{l}-22.94 \\
-21.62\end{array}$ & $\begin{array}{l}9.74 \\
7.86\end{array}$ & $\begin{array}{l}(-42.04 ;-3.85) \\
(-37.02 ;-6.22)\end{array}$ & $\begin{array}{l}.019 \\
.006\end{array}$ \\
\hline & GHQ-28 & -2.87 & 0.57 & $(-3.98 ;-1.75)$ & .000 \\
\hline & $\begin{array}{l}\text { Time } 1^{5} \\
\text { Time } 2\end{array}$ & $\begin{array}{l}3.09 \\
8.10\end{array}$ & $\begin{array}{l}3.74 \\
2.75\end{array}$ & $\begin{array}{l}(-4.24 ; 10.42) \\
(2.71 ; 13.49)\end{array}$ & $\begin{array}{l}.409 \\
.003\end{array}$ \\
\hline \multirow[t]{3}{*}{$\begin{array}{l}\text { ROLE EMOTIONAL } \\
\text { (RE) }\end{array}$} & $\begin{array}{l}\text { Frequency of angina } a^{1}(\geq 1 \text { between baseline- } 3 \text { months) } \\
\text { Frequency of angina ( } \geq 1 \text { between } 3 \text { and } 6 \text { months) }\end{array}$ & $\begin{array}{c}-15.42 \\
6.46\end{array}$ & $\begin{array}{l}8.71 \\
9.35\end{array}$ & $\begin{array}{l}(-32.49 ; 1.65) \\
(-11.87 ; 24.80)\end{array}$ & .077 \\
\hline & GHQ-28 & -2.20 & 0.80 & $(-3.76 ;-0.64)$ & .006 \\
\hline & $\begin{array}{l}\text { Time } 1^{5} \\
\text { Time } 2\end{array}$ & $\begin{array}{l}10.90 \\
-0.68\end{array}$ & $\begin{array}{l}3.09 \\
7.26\end{array}$ & $\begin{array}{c}(4.84 ; 16.96) \\
(-14.90 ; 13.55)\end{array}$ & .000 \\
\hline
\end{tabular}


Table 3 Generalized Estimating Equation models for MEN of SF-36. (Continued)

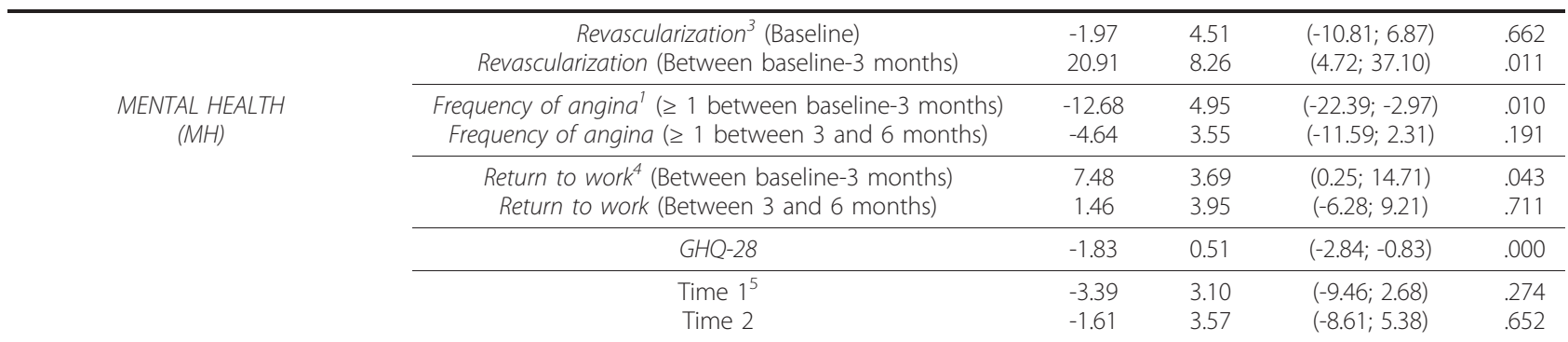

${ }^{1}$ Reference Category: No episode of angina occurred during the whole period.

${ }^{2}$ Reference Category: No rehospitalization occurred during the whole period.

${ }^{3}$ Reference Category: No revascularization occurred during the whole period.

${ }^{4}$ Reference Category: No return to work occurred during the whole period.

${ }^{5}$ Reference Category: Time 0: Baseline.

Time 1: 3 months.

Time 2: 6 months.

men. Likewise, the presence of risk factors did not have a special impact on either gender. On the other hand, revascularization was identified as a factor affecting the quality of life of the female population, especially when this was carried out during the second period of the study. In this respect, it is worth highlighting that revascularization was carried out earlier in the men, which may have conditioned the worse evolution observed in the women, who suffered higher frequencies of angina and rehospitalization during follow-up. Hemingway et al [30] and Aguado-Romero and co-workers [31] detail the tendency to operate less on women with coronary disease than on men, although the latter try to justify these differences by referring to limitations in their data. Likewise, Willingham and Kilpatrick [32] find evidence that women seem less likely to be diagnosed with an acute myocardial infarction (AMI) in the first place, despite a raised cTNT (cardiac Troponin T) value being a completely objective finding available to the clinician. The author explains that the reasons for this finding appear to be independent of the older age at which the females were affected in their study. Thus, other factors, such as the perception that women have a lower pre-test probability of infarction, may influence the clinician's discharge decision [32]. The different attitude to treatment among women may be another determining factor.

On the other hand, several studies have found that the evolution of HRQL differs between men and women after coronary surgery. Bute et al [33] concluded that women do not obtain the same benefit from CABG (Coronary Artery Bypass Grafting) surgery as men, and that the difference cannot be attributed to preoperative divergence. One possible explanation for this is that women's compromised HRQL is less related to cardiac health than men's, with other environmental and/or personality variables related to quality of life affecting women more than men [33].
One relevant aspect of the study which confirms the hypothesis formulated is the effect of the deterioration of mental health on the evolution of all the dimensions of HRQL, both in men and women. Previous studies have demonstrated substantial rates of depression during the first year after a myocardial infarction [10] and several authors found that anxiety and depression predicted HRQL 12 months after AMI [1,34]. Brink et al reported depression after an AMI as a common determinant of a lower PCS score in both men and women, but their study did not include any measures of comorbidity or clinical parameters [1]. In our study, mental health affected the evolution of the HRQL of both the men and women when adjusted for other variables. However, a higher percentage of the women than the men had baseline scores below 6 in the GHQ-28. This may indicate that women deal worse with the disease from the outset, but it is not possible to confirm this as mental health was not assessed prior to the coronary event.

In our study, the women's HRQL was lower than the men's at baseline. Likewise, while the men's HRQL improved at 6 months in nearly all the physical dimensions, and in Social Functioning, the women only improved in Role Physical, Physical Component Summary, and Social Functioning. This is partly in accordance with the results obtained by Emery and coworkers, [17] who show that men and women have increased scores in physical health over time, but women have significantly lower scores in physical dimensions across all assessments.

Lastly, a limitation of our study is the small sample size, due to drop-outs during follow-up. However, the small differences observed between the drop-outs and the patients that remained indicate that selection bias was minimal. Likewise it is also necessary to explain that although the patients were contacted three times 
Table 4 Generalized Estimating Equation models for WOMEN for Physical Dimensions of SF-36

\begin{tabular}{|c|c|c|c|c|c|}
\hline & VARIABLES & B & SE & C.I. (95\%) & Sig. \\
\hline & Previous history of CHD (Yes) & -18.33 & 4.34 & $(-26.84 ;-9.81)$ & .000 \\
\hline & Diagnostic group (AMI) & 14.52 & 4.46 & $(5.78 ; 23.27)$ & .001 \\
\hline & Comorbidity (Yes) & -9.64 & 4.51 & $(-18.48 ;-0.80)$ & .033 \\
\hline \multirow[t]{4}{*}{$\begin{array}{l}\text { PHYSICAL FUNCTIONING } \\
\text { (PF) }\end{array}$} & $\begin{array}{l}\text { Rehospitalization }{ }^{1} \text { (Between baseline3 months) } \\
\text { Rehospitalization (Between } 3 \text { and } 6 \text { months) }\end{array}$ & $\begin{array}{l}-9.41 \\
-18.07 \\
\end{array}$ & $\begin{array}{l}6.62 \\
7.47 \\
\end{array}$ & $\begin{array}{l}(-22.38 ; 3.56) \\
(-32.72 ;-3.43)\end{array}$ & $\begin{array}{l}.155 \\
.016\end{array}$ \\
\hline & GHQ-28 & -1.70 & 0.35 & $(-2.38 ;-1.01)$ & .000 \\
\hline & $\begin{array}{l}\text { Time } 1^{4} \\
\text { Time } 2\end{array}$ & 0.01 & $\begin{array}{l}4.16 \\
6.21\end{array}$ & $\begin{array}{c}(-8.14 ; 8.16) \\
(-10.95 ; 13.40)\end{array}$ & $\begin{array}{l}.998 \\
.844\end{array}$ \\
\hline & Age & -1.25 & 0.49 & $(-2.22 ;-0.28)$ & .011 \\
\hline \multirow[t]{3}{*}{$\begin{array}{l}\text { ROLE PHYSICAL } \\
\qquad \text { (RP) }\end{array}$} & $\begin{array}{l}\text { Frequency of angina }{ }^{2} \text { ( } \geq 1 \text { between baseline- } 3 \text { months) } \\
\text { Frequency of angina ( } \geq 1 \text { between } 3 \text { and } 6 \text { months) }\end{array}$ & $\begin{array}{l}-12.40 \\
-27.15\end{array}$ & $\begin{array}{l}14.72 \\
16.67\end{array}$ & $\begin{array}{c}(-41.25 ; 16.45) \\
(-59.82 ; 5.51)\end{array}$ & $\begin{array}{l}.400 \\
.103\end{array}$ \\
\hline & GHQ-28 & -4.36 & 0.55 & $(-5.44 ;-3.29)$ & 000 \\
\hline & $\begin{array}{l}\text { Time } 1^{4} \\
\text { Time } 2\end{array}$ & $\begin{array}{l}4.81 \\
30.81\end{array}$ & $\begin{array}{l}12.83 \\
10.23\end{array}$ & $\begin{array}{r}(-20.33 ; 29.95) \\
(10.76 ; 50.86)\end{array}$ & $\begin{array}{l}.708 \\
.003\end{array}$ \\
\hline \multirow{3}{*}{$\begin{array}{l}\text { BODY PAIN } \\
\quad(B P)\end{array}$} & Previous history of CHD (Yes) & -25.50 & 5.27 & $(-35.82 ;-15.18)$ & .000 \\
\hline & GHQ-28 & -0.99 & 0.46 & $(-1.90 ;-0.09)$ & .031 \\
\hline & $\begin{array}{l}\text { Time } 1^{4} \\
\text { Time } 2\end{array}$ & $\begin{array}{c}-0.50 \\
1.98\end{array}$ & $\begin{array}{l}5.44 \\
5.21\end{array}$ & $\begin{array}{l}(-11.15 ; 10.15) \\
(-8.24 ; 12.19)\end{array}$ & $\begin{array}{l}.927 \\
.705\end{array}$ \\
\hline \multirow[t]{3}{*}{$\begin{array}{l}\text { GENERAL HEALTH } \\
\text { (GH) }\end{array}$} & $\begin{array}{l}\text { Revascularization }^{3} \text { (Baseline) } \\
\text { Revascularization (Between baseline and } 3 \text { months) } \\
\text { Revascularization (Between } 3 \text { and } 6 \text { months) }\end{array}$ & $\begin{array}{c}-10.12 \\
7.16 \\
-17.07\end{array}$ & $\begin{array}{l}6.48 \\
9.84 \\
8.32\end{array}$ & $\begin{array}{l}(-22.82 ; 2.59) \\
(-12.12 ; 26.44) \\
(-33.38 ;-0.77)\end{array}$ & $\begin{array}{l}.119 \\
.466 \\
.040 \\
\end{array}$ \\
\hline & GHQ-28 & -2.14 & 0.33 & $(-2.78 ;-1.49)$ & .000 \\
\hline & $\begin{array}{l}\text { Time } 1^{4} \\
\text { Time } 2\end{array}$ & $\begin{array}{c}0.20 \\
-1.97\end{array}$ & $\begin{array}{l}4.06 \\
4.02\end{array}$ & $\begin{array}{l}(-7.75 ; 8.15) \\
(-9.85 ; 5.91)\end{array}$ & $\begin{array}{l}.961 \\
.624\end{array}$ \\
\hline \multirow{5}{*}{$\begin{array}{l}\text { PHYSICAL COMPONENT SUMMARY } \\
\text { (PCS) }\end{array}$} & Previous history of CHD (Yes) & -8.32 & 1.98 & $(-12.20 ;-4.45)$ & .000 \\
\hline & Diagnostic group (AMI) & 4.52 & 2.12 & $(0.36 ; 8.68)$ & .033 \\
\hline & $\begin{array}{l}\text { Frequency of angina } a^{2} \text { ( } \geq 1 \text { between baseline- } 3 \text { months) } \\
\text { Frequency of angina ( } \geq 1 \text { between } 3 \text { and } 6 \text { months) }\end{array}$ & $\begin{array}{c}0.83 \\
-10.58\end{array}$ & $\begin{array}{l}3.06 \\
2.72\end{array}$ & $\begin{array}{c}(-5.17 ; 6.83) \\
(-15.91 ;-5.24)\end{array}$ & $\begin{array}{l}.786 \\
.000\end{array}$ \\
\hline & GHQ-28 & -0.57 & 0.15 & $(-0.86 ;-0.27)$ & .000 \\
\hline & $\begin{array}{l}\text { Time } 1^{4} \\
\text { Time } 2\end{array}$ & $\begin{array}{l}2.46 \\
8.80\end{array}$ & $\begin{array}{l}2.47 \\
1.68\end{array}$ & $\begin{array}{l}(-2.38 ; 7.30) \\
(5.51 ; 12.09)\end{array}$ & $\begin{array}{l}.319 \\
.000\end{array}$ \\
\hline
\end{tabular}

${ }^{1}$ Reference Category: No rehospitalisation occurred during the whole period.

${ }^{2}$ Reference Category: No episode of angina occurred during the whole period.

${ }^{3}$ Reference Category: No revascularization occurred during the whole period.

${ }^{4}$ Reference Category: Time 0: Baseline.

Time 1: 3 months.

Time 2: 6 months.

before being considered drop-outs, their being given an appointment in the hospital's Department of Preventive Medicine, and not in the Department of Cardiology, could have influenced the number of drop-outs observed.

Another limitation in this study was that no information was collected regarding the outcome status of patients lost during follow-up. However, some informal data were explored revealing no particular selection bias.

On the other hand, a strength of the study is that it uses a method of analysis which is rarely used in healthcare research. This makes it possible to know the independent effect of the different variables on the evolution of HRQL, with a more accurate estimation of the parameters than traditional regression methods $[27,35,36]$.

\section{Conclusions}

There are differences between the evolution of the HRQL of the men and women in the study after a coronary attack. Mental health was the determinant most frequently associated with HRQL in both genders. However, other clinical determinants of HRQL differed between genders, emphasizing the importance of individualizing the intervention and the content of rehabilitation programs. Likewise, the recognition and treatment of mental disorders in these patients could be crucial. 
Table 5 Generalized Estimating Equations models for WOMEN for Mental Dimensions of SF-36.

\begin{tabular}{|c|c|c|c|c|c|}
\hline & VARIABLES & B & SE & C.I. $(95 \%)$ & Sig. \\
\hline \multirow{5}{*}{$\begin{array}{l}\text { VITALITY } \\
(V T)\end{array}$} & $\begin{array}{l}\text { Educational Level (Primary) } \\
\text { Educational Level (Secondary and University) }\end{array}$ & $\begin{array}{c}0.63 \\
13.23\end{array}$ & $\begin{array}{l}4.57 \\
5.00\end{array}$ & $\begin{array}{l}(-8.32 ; 9.58) \\
(3.44 ; 23.03)\end{array}$ & $\begin{array}{l}.890 \\
.000\end{array}$ \\
\hline & Previous history of CHD (Yes) & -11.39 & 4.63 & $(-20.46 ;-2.32)$ & .014 \\
\hline & $\begin{array}{c}\text { Revascularization }{ }^{7} \text { (Baseline) } \\
\text { Revascularization (Between baseline-3 months) } \\
\text { Revascularization (Between } 3 \text { and } 6 \text { months) }\end{array}$ & $\begin{array}{r}4.38 \\
26.16 \\
-39.69 \\
\end{array}$ & $\begin{array}{c}11.06 \\
19.88 \\
9.41 \\
\end{array}$ & $\begin{array}{l}(-17.30 ; 26.07) \\
(-12.82 ; 65.12) \\
(-58.13 ;-21.25) \\
\end{array}$ & $\begin{array}{l}.692 \\
.188 \\
.000 \\
\end{array}$ \\
\hline & GHQ-28 & -2.98 & 0.31 & $(-3.58 ;-2.37)$ & .000 \\
\hline & $\begin{array}{l}\text { Time } 1^{4} \\
\text { Time } 2\end{array}$ & $\begin{array}{l}0.56 \\
5.60\end{array}$ & $\begin{array}{l}5.19 \\
5.88\end{array}$ & $\begin{array}{l}(-9.62 ; 10.73) \\
(-5.93 ; 17.12)\end{array}$ & $\begin{array}{l}.915 \\
.341\end{array}$ \\
\hline \multirow{5}{*}{$\begin{array}{l}\text { SOCIAL FUNCTIONING } \\
\text { (SF) }\end{array}$} & $\begin{array}{c}\text { Educational Level (Primary) } \\
\text { Educational Level (Secondary and University) }\end{array}$ & $\begin{array}{c}1.09 \\
30.26 \\
\end{array}$ & $\begin{array}{l}6.57 \\
7.47 \\
\end{array}$ & $\begin{array}{l}(-11.78 ; 13.96) \\
(15.62 ; 44.91) \\
\end{array}$ & $\begin{array}{l}.869 \\
.000 \\
\end{array}$ \\
\hline & Previous history of CHD (Yes) & -23.40 & 7.05 & $(-37.22 ;-9.58)$ & .001 \\
\hline & $\begin{array}{l}\text { Revascularization }{ }^{7} \text { (Baseline) } \\
\text { Revascularization (Between Baseline-3 months) } \\
\text { Revascularization (Between } 3 \text { and } 6 \text { months) }\end{array}$ & $\begin{array}{c}10.40 \\
5.67 \\
-28.37\end{array}$ & $\begin{array}{l}11.82 \\
29.80 \\
26.63\end{array}$ & $\begin{array}{l}(-12.76 ; 33.56) \\
(-52.73 ; 64.08) \\
(-80.57 ; 23.83)\end{array}$ & $\begin{array}{l}.379 \\
.849 \\
.287\end{array}$ \\
\hline & GHQ-28 & -2.26 & 0.52 & $(-3.28 ;-1.24)$ & .000 \\
\hline & $\begin{array}{l}\text { Time } 1^{4} \\
\text { Time } 2\end{array}$ & $\begin{array}{c}8.40 \\
18.00\end{array}$ & $\begin{array}{l}6.27 \\
8.88\end{array}$ & $\begin{aligned}(-3.88 ; 20.69) \\
(0.60 ; 35.41)\end{aligned}$ & $\begin{array}{l}.180 \\
.043\end{array}$ \\
\hline \multirow[t]{3}{*}{ ROLE EMOTIONAL (RE) } & $\begin{array}{l}\text { Revascularization }{ }^{1} \text { (Baseline) } \\
\text { Revascularization (Between baseline-3 months) } \\
\text { Revascularization (Between } 3 \text { and } 6 \text { months) }\end{array}$ & $\begin{array}{l}-0.65 \\
-37.27 \\
-11.53\end{array}$ & $\begin{array}{l}16.70 \\
8.33 \\
27.03 \\
\end{array}$ & $\begin{array}{l}(-33.37 ; 32.08) \\
(-53.59 ;-20.95) \\
(-64.50 ; 41.44)\end{array}$ & $\begin{array}{l}.969 \\
.000 \\
.670\end{array}$ \\
\hline & GHQ-28 & -3.53 & 0.60 & $(-4.70 ;-2.36)$ & .000 \\
\hline & $\begin{array}{l}\text { Time } 1^{4} \\
\text { Time } 2\end{array}$ & $\begin{array}{c}-12.39 \\
1.28\end{array}$ & $\begin{array}{c}8.72 \\
15.61\end{array}$ & $\begin{array}{l}(-29.48 ; 4.69) \\
(-29.32 ; 31.87)\end{array}$ & $\begin{array}{l}.155 \\
.935\end{array}$ \\
\hline \multirow{4}{*}{$\begin{array}{l}\text { MENTAL HEALTH } \\
\text { (MH) }\end{array}$} & Previous history of CHD (Yes) & -8.21 & 3.16 & $(-14.40 ;-2.02)$ & .009 \\
\hline & $\begin{array}{l}\text { Rehospitalization }^{2} \text { (Between baseline- } 3 \text { months) } \\
\text { Rehospitalization (Between } 3 \text { and } 6 \text { months) }\end{array}$ & $\begin{array}{l}-6.75 \\
-21.69\end{array}$ & $\begin{array}{l}3.47 \\
9.95\end{array}$ & $\begin{array}{l}(-13.55 ; 0.05) \\
(-41.19 ;-2.18)\end{array}$ & $\begin{array}{l}.052 \\
.029\end{array}$ \\
\hline & GHQ-28 & -1.88 & 0.28 & $(-2.43 ;-1.34)$ & .000 \\
\hline & $\begin{array}{l}\text { Time } 1^{4} \\
\text { Time } 2\end{array}$ & $\begin{aligned}-1.41 \\
6.42\end{aligned}$ & $\begin{array}{l}3.30 \\
4.63\end{array}$ & $\begin{array}{l}(-7.87 ; 5.05) \\
(-2.65 ; 15.49)\end{array}$ & $\begin{array}{l}.669 \\
.165\end{array}$ \\
\hline \multirow[t]{4}{*}{$\begin{array}{c}\text { MENTAL COMPONENT SUMMARY } \\
\text { (MCS) }\end{array}$} & $\begin{array}{l}\text { Revascularization }{ }^{1} \text { (Baseline) } \\
\text { Revascularization (Between baseline-3 months) } \\
\text { Revascularization (Between } 3 \text { and } 6 \text { months) }\end{array}$ & $\begin{array}{c}2.70 \\
-3.07 \\
-25.75\end{array}$ & $\begin{array}{l}3.28 \\
4.58 \\
4.16\end{array}$ & $\begin{array}{c}(-3.72 ; 9.13) \\
(-12.05 ; 5.91) \\
(-33.90 ;-17.59)\end{array}$ & $\begin{array}{l}.410 \\
.502 \\
.000\end{array}$ \\
\hline & $\begin{array}{l}\text { Frequency of angina }{ }^{3} \text { ( } \geq 1 \text { between baseline- } 3 \text { months) } \\
\text { Frequency of angina ( } \geq 1 \text { between } 3 \text { and } 6 \text { months) }\end{array}$ & $\begin{array}{l}-4.40 \\
18.21\end{array}$ & $\begin{array}{l}3.67 \\
5.27\end{array}$ & $\begin{array}{l}(-11.60 ; 2.79) \\
(7.87 ; 28.54)\end{array}$ & $\begin{array}{l}.230 \\
.001\end{array}$ \\
\hline & GHQ-28 & -1.34 & 0.152 & $(-1.64 ;-1.04)$ & .000 \\
\hline & $\begin{array}{l}\text { Time } 1^{4} \\
\text { Time } 2\end{array}$ & $\begin{array}{l}-0.04 \\
-6.97\end{array}$ & $\begin{array}{l}2.41 \\
4.50\end{array}$ & $\begin{array}{l}(-4.77 ; 4.69) \\
(-15.79 ; 1.84)\end{array}$ & $\begin{array}{l}.986 \\
.121\end{array}$ \\
\hline
\end{tabular}

${ }^{1}$ Reference Category: No revascularization occurred during the whole period. ${ }^{2}$ Reference Category: No rehospitalisation occurred during the whole period.

${ }^{3}$ Reference Category: No episode of angina occurred during the whole period. ${ }^{4}$ Reference Category: Time 0: Baseline.

Time 1: 3 months.

Time 2: 6 months.

\section{Acknowledgements and Funding}

This study received financial support from the Department of Health, Regional Government of Andalusia, Spain (exp: 151/01).

\section{Author details}

'Área de Medicina Preventiva y Salud Pública. Universidad de Cádiz. Spain.

¿Servicio de Cardiologia, Hospital Universitario "Puerta del Mar". Spain.

\section{Authors' contributions}

MD has made substantial contributions to the conception and design of the paper and the analysis and interpretation of data. She has been involved in drafting the manuscript.
CR has participated in patient evaluations, data collection, and the analysis of data. RA has made substantial contributions to the clinical evaluation of the patients and the coordination of the hospital work. IF has made substantial contributions to the conception and design of the paper. She has been involved in revising the manuscript and she has given her final approval of the version to be sent. All the authors have read and approved the final manuscript.

\section{Competing interests}

The authors declare that they have no competing interests.

Received: 2 November 2010 Accepted: 27 May 2011

Published: 27 May 2011 


\section{References}

1. Brink E, Grankvist G, Karlson BW, Hallberg LR: Health-related quality of life in women and men one year after acute myocardial infarction. Qual Life Res 2005, 14(3):749-757.

2. Smith $H$, Taylor $R$, Mitchell A: A comparison of four quality of life instruments in cardiac patients: SF-36, QLI, QLMI, and SEIQoL. Heart 2000, 84(4):390-394

3. Tunstall-Pedoe H, Vanuzzo D, Hobbs M, Mahonen M, Cepaitis Z, Kuulasmaa K, Keil U: Estimation of contribution of changes in coronary care to improving survival, event rates, and coronary heart disease mortality across the WHO MONICA Project populations. Lancet 2000, 355(9205):688-700

4. Abbey SE, Stewart DE: Gender and psychosomatic aspects of ischemic heart disease. J Psychosom Res 2000, 48(4-5):417-423.

5. Brink E, Karlson BW, Hallberg LRM: Health experiences of first-time myocardial infarction: Factors influencing women's and men's healthrelated quality of life after five months. Psychology, Health and Medicine 2002, 7(1):5-16.

6. Ghali WA, Faris PD, Galbraith PD, Norris CM, Curtis MJ, Saunders LD, Dzavik V, Mitchell LB, Knudtson ML, Alberta Provincial Project for Outcome Assessment in Coronary Heart Disease (APPROACH) Investigators: Sex differences in access to coronary revascularization after cardiac catheterization: importance of detailed clinical data. Ann Intern Med 2002, 136(10):723-732

7. Kannel WB, Sorlie P, McNamara PM: Prognosis after initial myocardial infarction: the Framingham study. Am J Cardiol 1979, 44(1):53-59.

8. Schuster PM, Waldron J: Gender differences in cardiac rehabilitation patients. Rehabilitation nursing: the official journal of the Association of Rehabilitation Nurses 1991, 16(5):248-253.

9. O'Callaghan WG, Teo KK, O'Riordan J, Webb H, Dolphin T, Horgan JH: Comparative response of male and female patients with coronary artery disease to exercise rehabilitation. Eur Heart J 1984, 5(8):649-651.

10. Norris $C M$, Hegadoren K, Pilote L: Depression symptoms have a greater impact on the 1-year health-related quality of life outcomes of women post-myocardial infarction compared to men. Eur J Cardiovasc Nurs 2007, 6(2):92-98

11. Wiklund I, Herlitz J, Johansson S, Bengtson A, Karlson BW, Persson NG: Subjective symptoms and well-being differ in women and men after myocardial infarction. Eur Heart J 1993, 14(10):1315-1319.

12. Westin L, Carlsson R, Erhardt L, Cantor-Graae E, McNeil T: Differences in quality of life in men and women with ischemic heart disease. A prospective controlled study. Scand Cardiovasc J 1999, 33(3):160-165.

13. Beck CA, Joseph L, Belisle P, Pilote L: Predictors of quality of life 6 months and 1 year after acute myocardial infarction. Am Heart J 2001 142(2):271-279.

14. Mendes de Leon CF, Dilillo V, Czajkowski S, Norten J, Schaefer J, Catellier D, Blumenthal JA, Enhancing Recovery in Coronary Heart Disease (ENRICHD) Pilot Study: Psychosocial characteristics after acute myocardial infarction: the ENRICHD pilot study. Enhancing Recovery in Coronary Heart Disease. J Cardiopulm Rehabil 2001, 21(6):353-362.

15. Agewall $S$, Berglund $M$, Henareh L: Reduced quality of life after myocardial infarction in women compared with men. Clin Cardiol 2004 27(5):271-274.

16. Shumaker SA, Brooks MM, Schron EB, Hale C, Kellen JC, Inkster M, Wimbush FB, Wiklund I, Morris M: Gender differences in health-related quality of life among postmyocardial infarction patients: brief report. CAST Investigators. Cardiac Arrhythmia Suppression Trials. Womens Health 1997, 3(1):53-60

17. Emery CF, Frid DJ, Engebretson TO, Alonzo AA, Fish A, Ferketich AK, Reynolds NR, Dujardin JP, Homan JE, Stern SL: Gender differences in quality of life among cardiac patients. Psychosom Med 2004, 66(2):190-197

18. Pettersen Kl, Reikvam A, Rollag A, Stavem K: Understanding sex differences in health-related quality of life following myocardial infarction. Int J Cardiol 2008, 130(3):449-456.

19. Orfila F, Ferrer M, Lamarca R, Tebe C, Domingo-Salvany A, Alonso J: Gender differences in health-related quality of life among the elderly: the role of objective functional capacity and chronic conditions. Soc Sci Med 2006, 63(9):2367-2380

20. Norris CM, Ghali WA, Galbraith PD, Graham MM, Jensen LA, Knudtson ML, APPROACH Investigators: Women with coronary artery disease report worse health-related quality of life outcomes compared to men. Health Qual Life Outcomes 2004, 2:21.

21. Dixon T, Lim LL, Powell H, Fisher JD: Psychosocial experiences of cardiac patients in early recovery: a community-based study. J Adv Nurs 2000, 31(6):1368-1375.

22. Verbrugge LM: The twain meet: empirical explanations of sex differences in health and mortality. J Health Soc Behav 1989, 30(3):282-304.

23. Medical Outcomes Trust: Manual de puntuación de la versión española del cuestionario de salud SF-36 Barcelona: Institut Municipal d'nvestigació Mèdica, Unitat de Recerca en Serveis Sanitaris; 2000.

24. Lobo A, Pérez-Echeverría M, Artal J: Validity of the scaled version of the General Health Questionnaire (GHQ-28) in a Spanish population. Psychol Med 1986, 16(1):135-140.

25. Vázquez Barquero J, Ochoteco A, Padierna Acero J, Antón Sainz J, Arenal González A, Peña C: El cuestionario de salud general (GHQ) como instrumento de "screening" de patología psiquiátrica en enfermos cardiológico. Actas Luso Esp Neurol Psiquiatr Cienc Afines 1982, 10(1):21-32

26. Twisk J, de Vente W: Attrition in longitudinal studies. How to deal with missing data. J Clin Epidemiol 2002, 55(4):329-337.

27. Ballinger GA: Using Generalized Estimating Equations for Longitudinal Data Analysis. Organizational Research Methods 2004, 7(2):127-150.

28. Cui J, Qian G: Selection of working correlation structure and best model in GEE analyses of longitudinal data. Communications in Statistics: Simulation and Computation 2007, 36(5):987-996.

29. Van Jaarsveld C, Sanderman R, Ranchor A, Ormel J, van Veldhuisen D, Kempen G: Gender-specific changes in quality of life following cardiovascular disease: a prospective study. J Clin Epidemiol 2002, 55(11):1105-1112.

30. Hemingway H, McCallum A, Shipley M, Manderbacka K, Martikainen P Keskimaki I: Incidence and prognostic implications of stable angina pectoris among women and men. JAMA 2006, 295(12):1404-1411.

31. Aguado-Romeo MJ, Marquez-Calderon S, Buzon-Barrera ML, por los investigadores del grupo VPM-IRYSS-Andalucia: Differences between women's and men's access to interventional cardiovascular procedures at public hospitals in Andalusia (Spain). Rev Esp Cardiol 2006, 59(8):785-793.

32. Willingham SA, Kilpatrick ES: Evidence of gender bias when applying the new diagnostic criteria for myocardial infarction. Heart 2005 , 91(2):237-238

33. Phillips Bute B, Mathew J, Blumenthal JA, Welsh-Bohmer K, White WD Mark D, Landolfo K, Newman MF: Female gender is associated with impaired quality of life 1 year after coronary artery bypass surgery. Psychosom Med 2003, 65(6):944-951.

34. Lane D, Carroll D, Ring C, Beevers DG, Lip GY: Mortality and quality of life 12 months after myocardial infarction: effects of depression and anxiety. Psychosom Med 2001, 63(2):221-230

35. Nores M, Díaz M: Construcción de Modelos Gee para Variables con Distribución Simétrica. Sociedad Argentina de Estadística 2005, 9:43-63.

36. Twisk JW: Longitudinal data analysis. A comparison between generalized estimating equations and random coefficient analysis. Eur J Epidemiol 2004, 19(8):769-776.

\section{Pre-publication history}

The pre-publication history for this paper can be accessed here: http://www.biomedcentral.com/1471-2261/11/24/prepub

doi:10.1186/1471-2261-11-24

Cite this article as: Dueñas et al.: Gender differences and determinants of health related quality of life in coronary patients: a follow-up study. BMC Cardiovascular Disorders 2011 11:24. 